\title{
Author Correction: Factors of the bone marrow microniche that support human plasma cell survival and immunoglobulin secretion
}

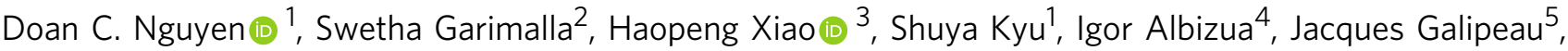 \\ Kuang-Yueh Chiang ${ }^{6}$, Edmund K. Waller ${ }^{7}$, Ronghu Wu (10 ${ }^{3}$, Greg Gibson (10 ${ }^{2}$, James Roberson ${ }^{8}$, Frances E. Lund ${ }^{9}$, \\ Troy D. Randall ${ }^{10}$, Iñaki Sanz ${ }^{11,12} \&$ F. Eun-Hyung Lee ${ }^{1,12}$
}

Correction to: Nature Communications; https://doi.org/10.1038/s41467-018-05853-7; published online 12 September 2018

The original version of this Article omitted a declaration from the Competing interests statement, which should have included the following: 'A patent has been applied for by Emory University with F.E.L., I.S., and D.C.N. as named inventors. The patent application number is PCT/US2016/036650'. This has now been corrected in both the PDF and HTML versions of the Article.

Published online: 17 January 2019

\begin{abstract}
(i) Open Access This article is licensed under a Creative Commons Attribution 4.0 International License, which permits use, sharing, adaptation, distribution and reproduction in any medium or format, as long as you give appropriate credit to the original author(s) and the source, provide a link to the Creative Commons license, and indicate if changes were made. The images or other third party material in this article are included in the article's Creative Commons license, unless indicated otherwise in a credit line to the material. If material is not included in the article's Creative Commons license and your intended use is not permitted by statutory regulation or exceeds the permitted use, you will need to obtain permission directly from the copyright holder. To view a copy of this license, visit http://creativecommons.org/licenses/by/4.0/.
\end{abstract}

(C) The Author(s) 2019

\footnotetext{
${ }^{1}$ Division of Pulmonary, Allergy, Critical Care \& Sleep Medicine, Emory University, Atlanta, GA, USA. ${ }^{2}$ School of Biological Sciences, Georgia Institute of Technology, Atlanta, GA, USA. ${ }^{3}$ School of Chemistry and Biochemistry, Georgia Institute of Technology, Atlanta, GA, USA. ${ }^{4}$ Department of Human Genetics, Emory University, Atlanta, GA, USA. ${ }^{5}$ Department of Medicine \& University of Wisconsin Carbone Cancer Center, University of Wisconsin in Madison, Madison, WI, USA. ${ }^{6}$ Division of Hematology \& Oncology, University of Toronto, Toronto, ON, Canada. ${ }^{7}$ Pediatrics \& Hematology/Oncology, Emory University, Atlanta, GA, USA. ${ }^{8}$ Department of Orthopedics, Emory University, Atlanta, GA, USA. ${ }^{9}$ Department of Microbiology, University of Alabama at Birmingham, Birmingham, AL, USA. ${ }^{10}$ Division of Clinical Immunology \& Rheumatology, University of Alabama at Birmingham, Birmingham, AL, USA. ${ }^{11}$ Division of Rheumatology, Emory University, Atlanta, GA, USA. ${ }^{12}$ Lowance Center for Human Immunology, Emory University, Atlanta, GA, USA. Correspondence and requests for materials should be addressed to F.-H.L. (email: f.e.lee@emory.edu)
} 